\title{
DALMATINSKA OBITELJ RADNIĆ U VOJNOJ POVIJESTI DALMACIJE (17. - 18. STOLJEĆE)
}

Lovorka ČORALIĆ

Hrvatski institut za povijest

Zagreb, Hrvatska
UDK: 355.1 : 929.52 Radnić" $16 / 17^{\text {“ }}$

DOI: $10.21857 / \mathrm{y} 26 \mathrm{kec} 4 \mathrm{z} 89$

Izvorni znanstveni rad

Prihvaćeno: 17. ožujak 2021.

Rad je upravljen na raščlambu arhivskog gradiva i historiografskih podataka koji se odnose na dalmatinsku obitelj Radnić, njezine odvjetke i ulogu u vojnoj povijesti Dalmacije, ali i šireg područja mletačkih stečevina od konca 17. do konca 18. stoljeća. Utvrđuju se prvi početci spominjanja obitelji u mletačkim izvorima (kraj 17. stoljeća), kao i nastavak njihove uključenosti u mletačke prekomorske kopnene postrojbe, ponajprije one koje se odnose na konjaništvo (Cavalleria Croati i Croati a cavallo). U radu se kronološkim slijedom prati djelovanje pojedinih članova obitelji u mletačkoj vojsci (ponajprije u konjaništvu), a posebna je pozornost posvećena kapetanu Ivanu (oko 1680. - 1756.), djelatnom u vrijeme Drugog morejskog rata, kao i njegovu sinu Antunu (1723. - 1799.) koji je postigao čin pukovnika. U tom se kontekstu, uz podatke o njihovu napredovanju, donosi i podrobnija raščlamba sastava satnija kojima su navedeni osobno zapovijedali te iznosi zavičajno podrijetlo njihova vojnog ljudstva. U prilozima na kraju rada donose se i popisi sastava nekih od njihovih satnija, načinjeni prema gradivu iz Archivio di Stato di Venezia.

Ključne riječi: obitelj Radnić, Dalmacija, Mletačka Republika, vojna povijest, rani novi vijek.

\section{UVODNE NAPOMENE. CILJ RADA}

U prošlim stoljećima važnu su ulogu u istočnojadranskoj i mletačkoj vojnoj povijesti imale kopnene postrojbe Serenissime unovačene na širem području hrvatskog uzmorja, ali i u njegovoj unutrašnjosti. To su ponajprije profesionalne jedinice konjanika (Croati a cavallo, Cavalleria Croati) i pješaka (Fanti oltramarini) koje se učestalo bilježe u vrijeme mletačko-osmanskih ratova u 17. i početkom 18. stoljeća (Kandijski rat: 1645. - 1669.; Morejski rat: 1684. - 1699. i Drugi morejski ili Mali rat: 1714. - 1718.). Njihove jedinice, raspoređene u pukovnije i njima pripadajuće satnije, bile su izrazito mobilne i dobro osposobljene za ratovanje (kao i za čuvanje mira) od sjevera Dalmacije i Boke kotorske do Peloponeza, pridonoseći očuvanju mletačke Terraferme i prekomorskih stečevina Republike svetog Marka. Podatci o navedenim postrojbama, kao i o njihovim zapovjednicima, u najvećem su broju sačuvani 
su u Archivio di Stato di Venezia (fond Inquisitori sopra l'amministrazione dei pubblici ruoli) i Državnom arhivu u Zadru (fondovi Generalni providuri za Dalmaciju i Albaniju, Bilježnici Zadra i drugi). Njihova znanstvena raščlamba vrijedna je za proučavanje svekolikih sastavnica vojne povijesti područja koji su se nalazili u sastavu Mletačke Republike. ${ }^{1}$ U sklopu ovih istraživanja obrađeni su i u znanstvenim radovima prezentirani brojni visoki mletački časnici (iz pješačkih i konjaničkih jedinica: pukovnija i njima pripadajućih satnija) zavičajem ponajprije iz Dalmacije i Boke kotorske je te pritom podrobno raščlanjen i sastav njihova vojnog ljudstva. ${ }^{2}$

1 O mletačkim vojnim snagama u ranom novom vijeku, posebice $s$ obzirom na novačenja duž istočnog Jadrana, podrobnije vidi bilješku broj $1 \mathrm{u}$ radu Lovorke Čoralić, Albanski vojnici u mletačkim prekojadranskim kopnenim postrojbama (18. stoljeće), Povijesni prilozi, god. 37, br. 54, Zagreb, 2018., 183 - 214. Zasebno o postrojbama mletačkih prekomorskih pješaka vidi u: Lovorka Čoralić, Maja KaTUšić, Kotorski plemići Frano Buća, Gabrijel Vraćen i Nikola Paskvali - časnici mletačkih prekojadranskih vojnih postrojbi (prva polovica XVIII. st.), Povijesni prilozi, god. 31, br. 42, Zagreb, 2012., 250 - 252. U tim se radovima mogu o navedenoj problematici pronaći i druge uporabljive bibliografske jedinice. Također, izrazito važne podatke o onodobnom ustroju vojnih snaga u Mletačkoj Dalmaciji vidi u: Nikola MARKulin, Mletačka vojna organizacija u Dalmaciji i Boki od Morejskog rata (1684. - 1699.) do Požarevačkog mira 1718., doktorska disertacija, Sveučilište u Zadru, Zadar, 2015.

2 Vidi primjerice neke radove: Lovorka Čoralıć, Od zapovjednika hrvatske konjice do gorljivih autonomaša - šibenska obitelj Fenzi (XVII. stoljeće - početak XX. stoljeća), Povijesni prilozi, god. 30, br. 41, Zagreb, 2011., 203 - 231; Lovorka Čoralıć, Mletački pukovnik Ivan Krapović iz Maina (prva polovica 18. stoljeća), Arbivski zapisi, god. 18, br. 2, Cetinje, 2011., 81 - 106; Lovorka Čoralıć, Zadarski patricij Šimun Nassi - pukovnik hrvatskih konjanika u mletačkoj vojsci (početak 18. stoljeća), Povijesni zbornik - godišnjak za kulturu i povijesno naslijede, god. 4, br. 5, Osijek, 2012., 7 - 31; Lovorka Čoralı́́, Šibenski plemić Nikola Divnić (1654. - 1734.) - pukovnik hrvatske lake konjice (Cavalleria Croati), Radovi Zavoda za povijesne znanosti HAZU u Zadru, sv. 54, Zagreb - Zadar, 2012., 125 - 145; Lovorka Čoralić, Mletački časnik Nikola Visković i sastav vojnoga ljudstva njegove prekomorske pukovnije početkom 18. stoljeća, Historijski zbornik, god. LXV, br. 2, Zagreb, 2012., 365 - 385; Lovorka ČorAlIć, Zadarski patricij Lujo Detriko (1672. 1749.) - zapovjednik hrvatske konjice (Cavalleria Croati), Zbornik Odsjeka za povijesne znanosti Zavoda za povijesne i društvene znanosti HAZU, sv. 32, Zagreb, 2014., 99 - 129; Lovorka Čoralić, Maja Katušıć, Andrija Mladinić i Mihovil Anđelo Filiberi - časnici postrojbe Croati a cavallo (iz društvene i vojne povijesti Dalmacije u XVIII. stoljeću), Povijesni prilozi, god. 28, br. 37, Zagreb, 2009., 247 - 282; Lovorka Čoralić, Maja KATUšić, Od afričke obale do dalmatinske prijestolnice - mletački general Marko Antun Bubić (1735. - 1802.), Zbornik Odsjeka za povijesne znanosti Zavoda za povijesne i društvene znanosti HAZU, sv. 28, Zagreb, 2010., 139 - 172; Lovorka Čoralić, Maja Katušıć, Peraštanin Tripun Štukanović (+ 1769) - pukovnik mletačkih oltramarina, Anali Zavoda za povijesne znanosti HAZU u Dubrovniku, sv. 50, Zagreb - Dubrovnik, 2012., 385 - 410; Lovorka Čoralić, Maja KaTušić, Hrvatski vojnici u posljednjim danima Mletačke Republike kapetan Nikola Bolica i njegovi Fanti oltramarini, u: Ascendere historiam. Zbornik u čast Milana Kruheka, ur. Marija Karbić, Hrvoje Kekez, Ana Novak i Zorislav Horvat, Zagreb, 2014., 197 - 208; Lovorka Čoralić, Maja Katušıć, Pukovnici, bojnici, kapetani - časnici iz kaštelanske obitelji Kumbat u službi Mletačke Republike (18. stoljeće), Radovi Zavoda za povijesne znanosti HAZU 
Središnja tema ovoga rada, koji je nastavak proučavanja visokih časnika u mletačkoj vojsci hrvatskog podrijetla, upravljena je na dalmatinsku obitelj Radnić. Rad se zasniva na uporabi prethodno spomenutog gradiva iz zadarske i mletačke državne pismohrane, a korištena je i odgovarajuća znanstvena literatura koja se izravno odnosi na obitelj Radnić i njezine odvjetke i njihovu vojnu djelatnost. Kronološkim slijedom spominjanja obradit ćemo pojedine članove obitelji Radnić, poglavito one koji su djelovali u profesionalnim postrojbama i tijekom karijere obnašali određene činove, a u sklopu raščlambe donijet ćemo i sažet opis sastava njihovih satnija i pukovnija. Posebna pozornost bit će poklonjena Radnićima koji su djelovali u konjaničkim postrojbama, gdje ih i najučestalije bilježimo kao zapovjednike satnija ili pukovnija. Rad je također pokušaj rasvjetljavanja povijesti jedne dalmatinske vojničke obitelji koja je imala i zapaženu ulogu u društvenom životu sredina u kojima je živjela i djelovala.

\section{RAŠČLAMBA ARHIVSKIH SPISA}

Prvi član obitelji Radnić koji se, prema našim saznanjima, spominje u izvorima i literaturi je Nikola, pripadnik lokalnih vojnih snaga (bandiera) pod vodstvom harambaše Stjepana Andrića 1684. godine te za kojega se napominje da je iz Drniša. ${ }^{3}$ Sljedeći Radnić o kojemu imamo više podataka je Grgur (oko 1655. - poslije 1718.). Godine 1684. također je uključen u teritorijalne vojne

u Zadru, sv. 57, Zagreb - Zadar, 2015., 145 - 183; Lovorka Čoralić, Maja KATušıć, Kotoranin Tripun Gregorina (1719-1791) - pukovnik hrvatskih konjanika (Croati a cavallo), Anali Zavoda za povijesne znanosti HAZU u Dubrovniku, sv. 55/2, Zagreb - Dubrovnik, 2017., 375 - 406; Lovorka Čoralić, Maja KATUŠIĆ, Jerolim Smeća - pukovnik mletačkih prekomorskih pješačkih postrojbi (druga polovica 18. stoljeća), Radovi Zavoda za povijesne znanosti HAZU u Zadru, sv. 59, Zagreb - Zadar, 2017., 289 - 314; Lovorka ČorALIć, Nikola MAR KULIN, Šibenski plemić Mihovil Zavorović - zapovjednik mletačkih pješačkih postrojbi u završnim desetljećima 18. stoljeća, u: Zbornik Šibenik od prvog spomena, ur. Iva Kurelac, Šibenik - Zagreb, 2018., 301 - 317; Lovorka Čoralić, Nikola Mar KUlin, Kotorski plemić Benedikt Paskvali (1704. - 1790.) - zapovjednik mletačkih prekomorskih pješačkih postrojbi, Acta Histriae, god. 26, sv. 2, Koper, 2018., 393 428; Lovorka Čoralić, Nikola Markulin, Vojni inženjer Antun Marković (u. 1767.) i njegova pješačka pukovnija, Radovi Zavoda za povijesne znanosti HAZU u Zadru, sv. 60, Zagreb - Zadar, 2018., 167 - 204; Lovorka Čoralić, Nikola MAR KULIN, Kotorski plemić i zapovjednik mletačkih prekomorskih pješaka Stjepan Buća i sastav njegove pukovnije (prva polovica 18. stoljeća), Povijesni prilozi, god. 38, br. 56, Zagreb, 2019., 261 - 294; Lovorka Čoralić, Nikola MAR Kulin, Trogirski plemići Michieli Vitturi - visoki časnici mletačkih prekomorskih kopnenih postrojbi u drugoj polovici 18. stoljeća, Radovi Zavoda za povijesne znanosti HAZU u Zadru, sv. 61, Zagreb Zadar, 2019., $361-405$.

3 Karlo Koson, Drniška krajina za turskoga vladanja, Kačić. Zbornik Franjevačke provincije Presv. Otkupitelja, sv. 11, Split, 1979., 188. 
snage, ali u jedinici harambaše Mije Stipševića Peraice. ${ }^{4}$ Tijekom Morejskog rata istaknuo se u bitkama kod Uskoplja, Rame, Glamoča, Mostara, Čitluka i Livna te u nekoliko navrata bio ranjen. Za zasluge mu je generalni providur Dalmacije i Albanije Alessandro Molin 1689. godine dao na korištenje kuću u Drnišu i 60 kanapa zemlje u Slivnu, a godinu dana poslije mlinicu na Roškom slapu. Godine 1695. imenovan je serdarom Drniša uz plaću od 12 dukata mjesečno. ${ }^{5}$ Početkom 18. stoljeća (1703.) serdar Grgur Radnić odlikovan je odlukom generalnog providura Marina Zane u Duždevoj palači s pet kolajni i dvije zlatne medalje te naslovom cavaliere di San Marco (23. 6. 1703.), a stekao je (doživotno i kao dodatak na plaću) i dodatnih pet dukata mjesečne potpore. ${ }^{6}$ Naposljetku, 1706. godine agregiran je u obnovljeno Veliko vijeće Skradina. ${ }^{7}$

Iako ne možemo biti sasvim sigurni, čini se da je Grgur imao istoimenog sina koji je odlukom generalnog providura Angela Ema 1716. godine takoder imenovan drniškim serdarom. ${ }^{8}$ Dvije godine poslije isti je Grgur prema ispravi providura Alvisea Moceniga imenovan vrličkim serdarom s plaćom od dvadeset dukata. ${ }^{9}$ Drugi sin kavaljera Grgura bio je Mihovil, zapažen sudionik u borbama za Glamoč tijekom Drugog morejskog rata. ${ }^{10}$ Treći Grgurov sin bio je Antun koji se 1701. - 1711. godine spominje kao kapetan satnije postrojbe Croati a cavallo u skupu pukovnije kojom je zapovijedao zadarski plemić Karlo Benja (Begna), ${ }^{11}$ a potom do smrti (15. srpnja 1715.) djeluje u istom činu u pukovniji Šimuna Nassija. Satniju Antuna Radnića preuzeo je njegov brat Ivan (oko 1680. - 1756.), zabilježen u pukovniji Nassi kao kapetan od 1716. godine. ${ }^{12}$ Ivan Radnić bio je, kako se navodi u povelji generalnog providura Alvisea Moceniga iz 1. siječnja 1718., zapaženi sudionik Drugog morejskog rata. Istaknuo se u borbama u okolici Livna, a za zasluge je tada imenovan

4 K. Kosor, Drniška krajina za turskoga vladanja, 192.

5 Državni arhiv u Zadru (dalje: DAZD), Generalni providuri za Dalmaciju i Albaniju (dalje: HRDAZD-1-GPDA), Daniele Dolfin, kut. 60, sv. 3, fol. 285', 15. II. 1695.).

6 HR-DAZD-1-GPDA, Marin Zane, kut. 68, sv. 2, fol. 68-69' (23. VI. 1703.).

7 Ivan Grgić, Obnova vlasteoske općine u Skradinu 1706. godine, Zadarska revija, br. 2, Zadar, 1958., 152 - 153; Ivo BABIĆ, Skradin i njegovo podrućje u proślosti, Skradin, 1986., 33; Mladen ANDreis, Trogirsko plemstvo do kraja prve austrijske uprave u Dalmaciji (1805.), Trogir, 2006., 261.

$8 \quad$ K. Kosor, Drniš pod Venecijom (Prilog poznavanju prošlosti Drniša), Kačić. Zbornik Franjevačke provincije Presv. Otkupitelja, sv. 7, Split, 1975., 30.

9 HR-DAZD-1-GPDA, Alvise Mocenigo, kut. 87, sv. 3, fol. 82-84' (1. I. 1718.); N. Markulin, Mletačka vojna organizacija u Dalmaciji i Boki od Morejskog rata, 189.

10 HR-DAZD-1-GPDA, Alvise Mocenigo, kut. 87, sv. 3, fol. 82-84' (1. I. 1718.).

11 Archivio di Stato di Venezia, Inquisitori sopra l'amministrazione dei pubblici ruoli (dalje: ASVe0715-Inquisitori ... pubblici ruoli), b. 774 (Cavalleria Croati), Reggimento Carlo Begna.

12 Prethodno je bio u satniji brata Antuna. Vidi u: ASVe-0715-Inquisitori ... pubblici ruoli), b. 824 (Cavalleria Croati), Reggimento Simeone Nassi. 
zapovjednikom odnosno nadintendantom za područje Drniša, Knina i Vrlike, ali mu je za tu funkciju plaća ostala u razini kapetanske. ${ }^{13}$

$\mathrm{Na}$ ovome ćemo mjestu izdvojiti sastav njegovih vojnika prema popisu koji je također načinjen u Zadru 1. ožujka 1718. godine. ${ }^{14}$ Radnićeva je satnija tada brojila 39 časnika, dočasnika i običnih vojnika. Uz kapetana Ivana Radnića, kao nositelji činova bilježe se poručnik (Tenente) Nikola Bartanjaca, kornet (Cornetta) odnosno potporučnik Lelio Radnić15 te kaplari (Caporal) Petar Bardi, Milan Marković i Ivan Sikanica. ${ }^{16}$ Nažalost, samo za dio vojnika navedeno je njihovo pobliže zavičajno podrijetlo, a to su izrijekom naselja (Novigrad zadarski, Zadvarje, Albanija, Kosovo kraj Knina, Zagora i Češka). U ovom popisu nisu sadržani drugi podatci o vojnicima Radnićeve satnije koji se često unose u popise unovačenih vojnika (dob, statura boja kose), redovito je zabilježena boja konja koje su zaduživali Radnićevi Croati a cavallo. Prednjače čilaši (stor, storno), a nešto su manje spomenuti dorati (bai, baio) i vranci (mor, moro). Ne znamo kako se u budućnosti odvijala sudbina Radnićeve konjaničke satnije. $S$ obzirom na manjak podataka o vojnicima, ali i znakovitu činjenicu da je većina vojnika prekrižena s popisa, možemo $s$ velikom vjerojatnošću pretpostaviti da - osim u formalnom smislu - satnija nikada nije uspostavljena i upućena na dužnost. Vjerojatnije je da se Ivan Radnić u većoj mjeri posvetio nadintendantskom funkcijom u zaleđu Dalmacije, koju je obnašao do 1729. godine. Ipak, poznati su nam neki podatci iz njegova osobnog života. Prema podatcima Mladena Andreisa, vrsnog poznavatelja matičnih knjiga dalmatinskih gradova (posebice Trogira), Radnić je bio oženjen za Margaretu Smarić, udovu Hreljanović iz Kaštel Novog (preminula 1729.), a potom za Franku Ćipiko (Cippico) (preminula poslije 1756. godine), trogirsku plemkinju iz kaštelanskog ogranka. Čini se da je posljednjih desetljeća života Ivan živio u Kaštel Štafiliću (od oko 1720. godine) te potom u Kaštel Novom. ${ }^{17}$ Nadalje, 1735. godine spominje se ugovor o gradnji kuće za mletačkog časnika

13 HR-DAZD-1-GPDA, Alvise Mocenigo, kut. 87, sv. 3, fol. 82-84' (1. I. 1718.). Vidi i: N. MARKULIN, Mletačka vojna organizacija u Dalmaciji i Boki, 200.

14 ASVe-0715-Inquisitori ... pubblici ruoli), b. 825 (Cavalleria Croati), Reggimento Simeone Nassi. Vidi i: N. Markulin, Mletačka vojna organizacija u Dalmaciji i Boki, 200. Popis se donosi u Prilogu 1. na kraju rada.

15 Iako to možemo pretpostavljati, na osnovu postojećih saznanja nije moguće Lelija dovesti u izravnu vezu s ovdje razmatranom obitelji Radnić.

16 Naknadno je osnovnom popisu pridružen još jedan običan vojnik.

17 M. Andreis, Trogirsko plemstvo, 261. Vidi i stariji uradak Jakova Pere, Povijest Kaštel Štafilića, Kaštela, 1997., 123 - 124, 183. 
(naveden u činu pukovnika!) ${ }^{18}$ Ivana Radnića, načinjen u trogirskoj općinskoj kancelariji s protomajstorom Dominikom Scottijem. Doznajemo da Scotti nije završio kuću za pukovnika Radnića u predviđenom roku. Kao razlog se navodi nedostatak građevnog materijala koji Scottiju nije bio dostavljen, a koji je tražio posredstvom Frane Vuletina, opunomoćenog zastupnika (prokuratora) gradnje kuće kapetana Radnića. Od spomenutog Vuletina traži se da bude spreman dostaviti potraživani građevni materijal jer će u protivnom Scotti biti prisiljen napustiti gradnju. U dokumentu se, nažalost, ne navodi pobliža lokacija kuće koja je građena za Ivana Radnića, odnosno nalazi li se ona u Trogiru ili Kaštel Štafiliću te ju je danas teško locirati. ${ }^{19}$

Ivanovi su sinovi bili Grgur (1721. - 1728.) i Antun (1723. - 1799.), a potonji je koncem vojne karijere postigao i čin pukovnika. U spisima mletačke državne magistrature za novačenje prvi ga puta bilježimo 1758. u Veroni, u činu korneta u sastavu satnije kotorskog plemića i bojnika (Sargente maggiore) Tripuna Gregorine (pukovnija kotorskog plemića Franje Buća). ${ }^{20}$ Godinu dana poslije Antun je poručnik u osobnoj satniji istog Buće (popisanoj u Bresciji), ${ }^{21}$ da bi potom 1760. (Brescia), 1765. (Zadar), 1772. (Benkovac) i 1774. (Mletci) djelovao u satnijama Antuna Duplančića (pukovnija Franje Buća), kao i u osobnoj satniji tada već promoviranog pukovnika Duplančića. ${ }^{22}$ Godine 1775. Antun Radnić promoviran je u potkapetana (Capitan tenente) te se bilježi u bivšoj pukovniji preminulog pukovnika Antuna Duplančića, odnosno u njegovoj osobnoj satniji koju je preuzeo kapetan Marko Kažotić. ${ }^{23}$ Šest godina poslije zabilježeno je novo napredovanje Antuna Radnića. Dne 12. ožujka 1781. imenovan je kapetanom i uvršten kao zapovjednik satnije u pukovniju Tripuna Gregorine. Na tome je

18 Prema arhivskim saznanjima nemamo podatak da je Radnić stekao čin pukovnika i da je aktivno zapovijedao nekom pukovnijom. Moguće je da mu je čin dodijeljen faktično pred sam kraj vojne karijere te stoga u mletačkom arhivu nemamo podatke o satnijama njegove pukovnije. U tom slučaju riječ bi bila o počasnoj tituli (primjerice Colonnello riformato).

19 Lovorka Čoralić, Ivana Prijatelj Pavičić, Prilog poznavanju djelovanja graditeljske obitelji Scotti (crkva sv. Grgura u Lepenicama u trogirskoj zagori), Croatica christiana periodica, god. XXVI, br. 49, Zagreb, 2002., 142 - 143.

20 ASVe-0715-Inquisitori ... pubblici ruoli, b. 782 (Cavalleria Croati), Reggimento Francesco Bucchia.

21 Radnić je naveden kao naknadno dopisan. ASVe-0715-Inquisitori ... pubblici ruoli, b. 782 (Cavalleria Croati), Reggimento Francesco Bucchia.

22 ASVe-0715-Inquisitori ... pubblici ruoli, b. 782 - 784 (Cavalleria Croati), Reggimento Francesco Bucchia; Isto, b. 809 (Cavalleria Croati), Reggimento Antonio Duplancich.

23 ASVe-0715-Inquisitori ... pubblici ruoli, b. 809 (Cavalleria Croati), Reggimento Antonio Duplancich. Nije rijetko da se pukovnija nakon smrti aktualnog pukovnika i dalje neko vrijeme nazivala po njemu. U satniji u kojoj je zabilježen Radnić kao običan se vojnik spominje Ivan Radnić iz Trogira. 
mjestu naslijedio nedavno preminulog Marka Kažotića te se u rečenoj pukovniji bilježi u Mletcima 23. kolovoza 1781. godine. ${ }^{24}$

U pukovniji Tripuna Gregorine članovi obitelji Radnić bilježe se i u sljedećem pratećem razdoblju. Godine 1786. (1. kolovoza) u Kotoru je načinjen popis unovačenih vojnika u satniji Antuna Radnića. ${ }^{25}$ Osobna Radnićeva satnija brojila je 39 časnika, dočasnika i običnih vojnika. Među ovim vojnim ljudstvom bilježe se kadet Šime Radnić, kao i obični vojnik Josip Radnić iz Skradina. Časnički i dočasnički kadar u postrojbi tada su činili, uz kapetana Antuna Radnića, poručnik Petar Kadičić, kornet Jakov Lodena, kaplar Marko Sorari, vodnik (Marescalco) Antun Maraschini iz Verone i kurir (Seller) Jakov Prtenjača iz Polače. Dio vojnika naknadno je prekrižen, a na njihovo je mjesto u jedinicu prispjelo 37 novih vojnika, među kojima se, a u činu korneta, bilježi Ivan Martin Radnić. ${ }^{26} \mathrm{U}$ ovome popisu najčešće je zabilježeno zavičajno podrijetlo ljudstva (Grafikon 1). Prednjače Dalmatinci (77,63 \%) koji su - uz veće obalne gradove Zadar, Šibenik i Split - najčešće iz zaleđa (Drniška, Kninska, Vrlička i Imotska krajina i tamošnja naselja). S Apeninskog je poluotoka potjecalo 3,95 \% vojnika (Mletci, Verona, Vicenza), a na područje Boke (Kotor) i Istre (označeni kao de Istria) otpadalo je po 2,63 \% konjanika. Naposljetku, iako je očito riječ (prema prezimenima) o hrvatskom podrijetlu, uži zavičaj nije naveden u $13,16 \%$ upisa.

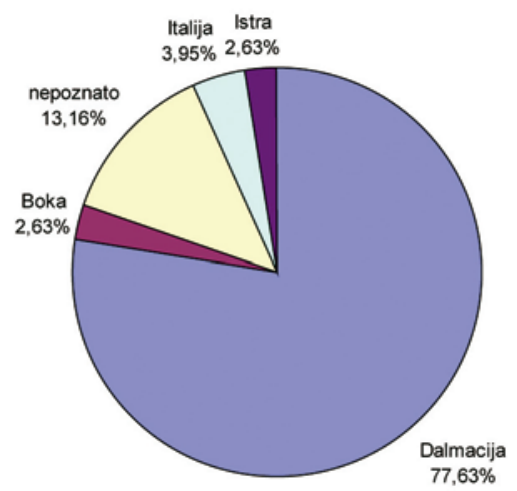

Grafikon 1. Zavičajno podrijetlo vojnika u satniji Antuna Radnića prema popisu iz 1786. godine

24 U istoj se satniji kao običan vojnik bilježi i Ivan Antunov Radnić iz Trogira koji je naknadno prekrižen iz popisa. Vidi u: ASVe-0715-Inquisitori ... pubblici ruoli, b. 816 (Cavalleria Croati), Reggimento Triffone Gregorina.

25 ASVe-0715-Inquisitori ... pubblici ruoli, b. 817 (Cavalleria Croati), Reggimento Triffone Gregorina. Popis se donosi u prilogu 2 na kraju rada.

26 Prema istraživanjima Mladena Andreisa, riječ je o Antunovu sinu, rođenom oko 1760. godine. Vidi u: M. ANDReIs, Trogirsko plemstvo, 261. 
Naposljetku, uz gotovo je svakog je vojnika opisana i boja njihovih konja. Najčešće su zastupljeni dorati i vranci, a značajno manje čilaši.

Godine 1788. u Kotoru je 3. kolovoza ponovno popisana Radnićeva satnija koja je i tada činila dio pukovnije Tripuna Gregorine. ${ }^{27}$ Veći dio vojnika popisanih u prethodnom primjeru i ovdje je prisutan (ukupno je zabilježeno 40 konjanika), a prezimenom Radnić spomenuti su, uz kapetana Antuna, kornet Ivan Martin Radnić i kadet Šime Radnić, pri čemu je za potonjeg, kao i u već obrađenom primjeru, izrijekom navedeno da potječe iz Skradina. U časničkom i dočasničkom dijelu ljudstva popisivači su zabilježili poručnika Petra Nakića, spomenutog korneta Ivana Martina Radnića, vodnika Antonija Maraschinija iz Verone, kaplare Marka Sorarija i Antuna Ruševića iz Budve, sedlara Gaspara Gollinija, kurira Jakova Prtenjaču te trubača (Trombetta) Leonarda Literića iz Zadra. U pukovniji Gregorina nalazimo Radnićevu satniju i u popisu iz 1788. godine (Mletci, 3. listopada). ${ }^{28}$ Satnija je brojila 40 vojnika, a sastav nalikuje onome iz prethodno raščlanjenog popisa. Od drugih osoba prezimena Radnić ponovno se bilježi kadet Šime Radnić za kojega je izrijekom navedeno da je sin Antuna.$^{29}$ Nadalje, ponovno je spomenut kornet Ivan Martin Radnić, a naknadno je kao običan vojnik dopisan Josip Andrijin Radnić iz Skradina. Antun Radnić imao je čin kapetana i 1789. godine kada se 22. listopada u Padovi bilježi kao zapovjednik satnije unutar iste pukovnije Gregorina. Već iduće godine (10. travnja 1790.) promoviran je u čin potpukovnika (Tenente Colonnello), a njegovu je satniju naslijedio kapetan Vicko Duplančić. ${ }^{30}$

Na samom kraju opstojanja Mletačke Republike Antun Radnić imenovan je pukovnikom. ${ }^{31} \mathrm{U}$ sastavu njegove pukovnije nalazile su se satnije kojima su zapovijedali kapetan Marko Dešković (Mletci, 6. svibnja 1797.),, kapetan Leonardo Giustiniani/Zustiniani (Mletci, 6. svibnja 1797.), ${ }^{33}$ kapetan Juraj Kadčić/Kačić (Mletci, 6. svibnja 1796.) ${ }^{34}$ i kapetan Bajo Nikolić (Mletci, 6. svibnja 1797.). Prema sadašnjim saznanjima raspolažemo sa samo jednim

29 Vjerojatno nije riječ o Antunovu sinu. $\mathrm{Na}$ to nas upućuju istraživanja rodoslovlja obitelji Radnić koje je načinio Mladen Andreis, a u kojima se spominju Antunovi sinovi, ali među njima ne i Šimun. Vidi u: M. ANDreIs, Trogirsko plemstvo, 261.

30 ASVe-0715-Inquisitori ... pubblici ruoli, b. 819 (Cavalleria Croati), Reggimento Triffone Gregorina.

31 ASVe-0715-Inquisitori ... pubblici ruoli, b. 826 (Cavalleria Croati), Reggimento Antonio Radnich.

32 Satnija je u Mletke prispjela al caso della segreta rivoluzione in questa città. U satniji je kao običan vojnik djelovao Mijat Radnić.

33 Satnija je u Mletke prispjela iz Roviga.

34 Satnija je u Mletke prispjela iz Vicenze. 


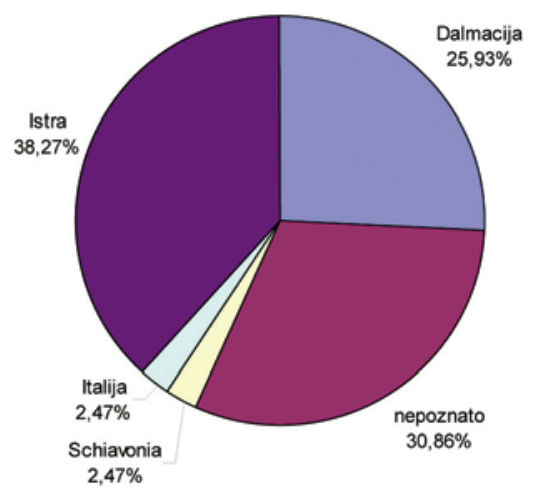

GRAFI KON 2. Zavičajno podrijetlo vojnika u satniji Antuna Radnička prema popisu iz 1796. godine

popisom vojnika u Radnićevoj osobnoj satniji (compagnia propria), a načinjen je u Mletcima na Silvestrovo 1796. godine..$^{35} \mathrm{Na}$ samom početku dokumenta sadržani su podatci o plaćama pojedinih časnika, dočasnika i običnih vojnika. Pukovniku Radniću tada je bilo namijenjeno 40 dukata, poručniku i kornetu 15, a kaplaru, kadetu i običnim vojnicima (Crovati) po 10 dukata. Satnija je u svome osnovnom sastavu brojila 66 časnika, dočasnika i običnih vojnika, od kojih je čak njih 29 naknadno prekriženo. Na njihovo je mjesto uvršteno 15 novih vojnika, od kojih su dvojica također u nekom trenutku prekrižena s popisa. Uz pukovnika Radnića, časnički i dočasnički kadar u satniji činili su poručnik Vicko Pasini, kornet Ivan Dominik Sfachiotto, kadet Nikola Vlasto, kaplari Ludovik Gaetani i Karlo Plasogat, vodnik Antun Marchesini, sedlar Filip Guđarović, kurir Frane Jurić te trubač Ivan Brunelli. Kada je riječ o naknadno dopisanim vojnicima, kao obnašatelji specijaliziranih službi u jedinici spominju se timpanist (Timpanista) Antonio Salsi i kapelan (Cappellano) Šimun Perić. Zavičajno podrijetlo ljudstva ove prvotno izrazito brojne satnije (Grafikon 2) ukazuje da je najviše vojnika dolazilo iz Istre (38,27\%), a kao mjesta (uz opću oznaku Istria) bilježe se Kopar, Marčana, Piran, Poreč, Pula, Umag i druga. Dalmaciju je kao mjesto zavičaja navelo 25,93 \% vojnika, a izrijekom se bilježe Drniš, Imotski, Klis, Omiš, Skradin, Split, Trogir, Vrlika, Zadar i druga mjesta. S neodređenog područja Schiavonia potjecalo je $2,47 \%$, a jednaki postotak otpada na vojnike s talijanskog područja (mletačka Terraferma). Naposljetku, na vojnike čije podrijetlo nije ubilježeno,

35 ASVe-0715-Inquisitori ... pubblici ruoli, b. 826 (Cavalleria Croati), Reggimento Antonio Radnich (Compagnia propria Antonio Radnich). Popis se donosi u prilogu 3 na kraju rada. 
ali koji su prema prezimenima zasigurno s područja istočnojadranske obale ili njezine bliže unutrašnjosti, otpada $30,86 \%$.

Ovdje je potrebno ukazati na neke pojedinosti. Naime, raščlambom gradiva odnosno popisa unovačenih vojnika opažamo da velik dio njih, a ovdje se to ponajprije odnosi na Istrane, potječe iz istih krajeva, najčešće mikroregija. Ti se vojnici mahom navode jedan iza drugoga, onako kako su pristupali popisivaču. Zavičajem iz istih krajeva, poznajući se i otprije međusobno, a našavši se u za njih neuobičajenim okolnostima i daleko od domovine, jednostavno su, ljudski, osjećali potrebu privrženosti i odanosti svojim sumještanima ili „braći po oružju“ iz istog kraja. U primjeru vojnika Radnićeve osobne satnije to se, uz Istrane, svakako može tvrditi i za vojnike iz nekih drugih sredina kao što je to u primjeru Dalmacije Drniš. Riječ je zapravo o vojnicima koji izvorno nisu bili profesionalni, već u svome kraju pripadnici teritorijalnih snaga - cernide ili krajine. Oni su, a to nije rijedak slučaj, na samom kraju opstojanja Serenissime, vrlo učestalo uključivani u profesionalne kopnene snage (ponajprije ipak u pješaštvo) i raspoređivani duž mletačke Terraferme odnosno u uporišta u Venetu i neposrednoj blizini samog grada na lagunama. Međutim, kako nije bila riječ o profesionalnim konjanicima, već o teritorijalnim jedinicama, njihovo uključivanje donosilo je problem obučenosti, stvarnog i kvalitetnog poznavanja vojnih vještina, ali i stalno prisutnih trvenja s "pravima“ Croati a cavallo koji su se bez sumnje smatrali superiornijima i u vojnoj službi vrjednijima. Otuda i činjenica da je iz osnovnog popisa prekriženo čak 29 vojnika za koje s velikom vjerojatnošću možemo tvrditi da su bili pripadnici cernida. Jesu uopće prispjeli na zborno mjesto ili su njihova imena samo fiktivno bila predviđena za popunjavanje satnije koja je, poput brojnih drugih, hrvatskim ljudstvom imala zadaću braniti kako Mletke, tako i ostala uporišta Republike svetog Marka duž Veneta, ostaje nam nepoznanica. Sigurno je ipak da čak ako su i sudjelovali odnosno bili unovačeni u Radnićevu osobnu postrojbu, ovi vojnici nisu u njoj djelovali kroz duže vrijeme te se većina njih vrlo brzo (radi već i same činjenice o skorom skončanju Privedre Republike) vratila u svoj kraj. ${ }^{36}$

Prilikom popisivanja ove osobne satnije pukovnika Antuna Radnića nisu sadržani osobni podatci o vojnicima (dob, statura, boja kose), već samo o njihovim konjima. Otprilike kao i u prethodnim popisima, ovi su hrvatski konjanici pretežito zaduživali dorate, vrance i čilaše, a u manjoj mjeri riđane. 
Naposljetku, završimo raščlambu dostupnih biografskih podataka o Antunu Radniću kraćim osvrtom na podatke iz njegova privatnog života, dostupne nam zahvaljujući istraživanjima već više puta citiranog Mladena Andreisa. Antun je bio oženjen (od 1748.) splitskom plemkinjom iz Nehaja Marijom Papali (1731. 1793.). Njegova je obitelj živjela na području Nehaja, prozvanog prema istoimenoj kuli zapadno od Kaštel Štafilića. Kako je kao visoki časnik često boravio u Zadru, ondje su krštena i njegova djeca. To su: Ivan (oko 1749. - 1757.), Dominika (1751.), Karlo (1753. - 57.), Mate (oko 1757.), Ivan Martin (oko 1760.), Elizabeta (1766.; udana za Andriju Lovrića iz Sinja 1798.), Franjo (rođen i umro 1767.) i Ivana (rođena 1768.). Godine 1793. sinovi Mate i konjanički poručnik i kornet Ivan Martin agregirani su u Veliko vijeće grada Trogira. Kao tamošnji plemići bilježe se i u godini pada Mletačke Republike (1797.). ${ }^{37}$

Sudbina obitelji Radnić u 19. stoljeću nije bila predmet istraživanja u ovom radu. Prema pisanju davnog, ali i dalje korisnog istraživača povijesti dalmatinskih plemićkih obitelji Carla Georga Friedricha Heyera von Rosenfelda, u trenutku austrijskog priznavanja plemstva 1823. godine spominje se Matija (Mate), čiji je sin bio Antun. Nakon tih saznanja ne raspolažemo uporabljivim podatcima o obitelji koja je, od Drniša do Zadra, imala zapaženu i još uvijek nedovoljno istraženu ulogu u vojnoj i društvenoj povijesti toga vremena. ${ }^{38}$

\section{ZAKLJUČAK}

U vrijeme mletačke uprave nad pretežitim dijelom Istre, Dalmacije i Boke kotorske važna je sastavnica pojedinih lokalnih sredina, kao i mletačkih stečevina u cjelini, bila vojna povijest. $\mathrm{O}$ toj problematici napisano je pregršt radova i osvijetljeni su brojni izrazito važni čimbenici. Međutim, prebogato gradivo iz Archivio di Stato di Venezia te iz Državnog arhiva u Zadru nije ni približno dovoljno istraženo i ostavlja brojne mogućnosti za istraživanje, raščlambu i znanstvenu prezentaciju. U ovome radu fokusirali smo se na jednu od obitelji koja nije potpuno nepoznata, ali čiji su članovi, iako velikim pregnućima i priznanjima od strane mletačkih vlasti, u historiografiji ipak bili tek samo djelomično obrađeni. Članovi dalmatinske obitelji Radnić podrijetlom, životom i djelovanjem bili su vezani za područja od Dalmatinske zagore (Drniš) do Skradina, Trogira i Zadra. U ovom radu bilježimo ih od kraja 17. stoljeća, točnije

37 M. ANDreis, Trogirsko plemstvo, 261.

38 Carl Georg Friedrich Heyer von Rosenfeld, Der Adel des Königreichs Dalmatien, Nürnberg, 1873., 75 . 
od Morejskog rata, pa sve do prvih desetljeća 19. stoljeća. Radnići su bili zapaženi sudionici mletačko-osmanskih vojnih sukoba, ali i istaknuti časnici i zapovjednici mletačkih profesionalnih postrojbi u mirnodopsko vrijeme. Njihova je poglavita prisutnost u vojnoj povijesti bila vezana za konjaništvo, odnosno elitne mletačke prekojadranske postrojbe Croati a cavallo. U navedenim su vojnim snagama Radnići obnašali visoke dužnosti tijekom više pokoljenja, a posebno su, ponajviše zahvaljujući sačuvanom gradivu, bili obrađeni Ivan i njegov sin Antun Radnić, kapetan i na kraju karijere (Antun) pukovnik. U radu je, koliko je to bilo moguće na osnovu postojećih saznanja $\mathrm{i}$ istraženosti gradiva, obrađena i njihova uloga $\mathrm{u}$ društvenoj povijesti sredina u kojima su djelovali, kao i njihov osobni odnosno obiteljski život i rodbinske veze. Sveukupno se može kazati kako se u ovom radu, koji se nastavlja na prethodna istraživanja prisutnosti i djelovanja dalmatinskih i bokeljskih obitelji u mletačkim prekomorskim kopnenim postrojbama, težilo dodatno rasvijetliti i pojasniti još jednu u nizu sastavnica hrvatske vojne povijesti kasnog ranog novog vijeka, ali i hrvatsko-mletačkih odnosa u cjelini.

Prilog 1. Sastav posade satnije kapetana Ivana Radnića (pukovnija Šimuna Nassija), načinjen u Zadru 1. ožujka 1718. (Archivio di Stato di Venezia, Inquisitori sopra l'amministrazione dei pubblici ruoli, b. 825, Cavalleria Croati, Reggimento Colonnello Simeone Nassi, Compagnia Capitan Zuanne Radnich)

1. Kapetan (Capitan): Ivan Radnić - dorat

2. Poručnik: (Tenente): Nikola Bartanjaca (Bartagnazza) - čilaš

3. Kornet (Cornetta): Lelio Radnić - čilaš

4. Kaplar (Caporal): Petar Bardi - Pavao - vranac

5. Kaplar (Caporal): Milan Marković - Marko - čilaš

6. Kaplar (Caporal): Ivan Sikanica - Urbo - Novigrad (zadarski) - dorat

Vojnici (Soldati):

7. Matija Severić - Stjepan - čilaš

8. Stjepan Ilišević - Miklo - Češka - čilaš

9. Bože Luketin - Franjo - vranac

10. Karlo d'Ungaria - Juraj - dorat

11. Mate Punović - Nikola - čilaš

12. Šimun Bogdanić - Bogdan

13. Mihovil Marasović - Toma - čilaš

14. Stjepan Jurlić - Marko - vranac

15. Filip Girić - Marko - dorat

16. Lazo Đalović - Luka - čilaš

17. Zaviša Labarčević - Savo - dorat

18. Petar Vušković - Pavao - dorat 
19. Matija Glavić - Petar - Zadvarje - vranac

20. Andrija Albanese - Ivan - Albanija - dorat

21. Matija Oštrić - Pavao - Albanija - čilaš

22. Ivan Carević - Ivan - vranac

23. Petar Petrović - Petar - Kosovo (kraj Knina) - vranac

24. Antun Kovačević - Jure - Zagora - vranac

25. Nikola Plosnić - Ivan - dorat

26. Antun Vuković - Martin - dorat

27. Dominik Fuina - Mihovil - čilaš

28. Petar Jobrić - Pavao - čilaš

29. Andrija Marasović - Toma - čilaš

30. Martin Balić - Ivan - dorat

31. Miho Vučić - Šimun - čilaš

32. Ivan Klepanović - Petar - vranac

33. Frane Vuletić - Šimun - dorat

34. Antun Zoberlić - Šimun - vranac

35. Martin Šubanić - Nikola - dorat

36. Toma Tolić - Ivan - čilaš

37. Ilija Medić - Božo - vranac

38. Petar Jukić - Mihovil - dorat

39. Križan Trusić - Vid - Drniš - dorat

Naknadno dopisan vojnik: Antun Milačić - Ilija - čilaš

Prilog 2. Sastav posade satnije kapetana Antuna Radnića (pukovnija Tripuna Gregorine), načinjen u Kotoru 1. kolovoza 1786. (Archivio di Stato di Venezia, Inquisitori sopra l'amministrazione dei pubblici ruoli, b. 817, Cavalleria Croati, Reggimento Colonnello Triffone Georgina, Compagnia Capitan Antonio Radnich)

1. Kapetan (Capitan): Antun Radnić - dorat

2. Poručnik (Tenente): Petar Kadičić - dorat

3. Kornet (Cornetta): Jakov Lodena - vranac

4. Kaplar (Caporal): Marko Sorari - vranac

5. Vodnik (Marescalco): Antonio Maraschini - Santo - Verona - dorat

6. Sedlar (Seller): Antun Pranić - Petar - Drniš - vranac

7. Kurir (Forier): Jakov Prtenjača - Stipan - Polača - dorat

8. Kadet (Cadetto): Šime Radnić - Antun - Skradin - čilaš (leardo)

Vojnici (Soldati):

9. Franjo Ivančević - Antun - Dalmacija - vranac

10. Frane Nađa (Naggia) - Ivan - Šibenik - dorat

11. Ivan Božić - Jure - Knin - vranac

12. Nikola Popović - Marko - Split - vranac

13. Nikola Trivić - Ilija - Drniš - vranac 
14. Ilija Pivalica - Mate - Vrlika - čilaš

15. Šime Odak - Antun - Kaštel Stari - vranac

16. Jovan Mioković - Marko - Pađane - čilaš

17. Frane Paskvalić - Tripun - Kotor - vranac

18. Josip Radnić - Andrija - Skradin - vranac

19. Jerolim Maschinel - Frane - Istra - vranac ${ }^{39}$

20. Šimun Žmirić - Ivan - Zadar - vranac

21. Filip Šuljac - Mijo - Žitnić

22. Jakov Paskvali - Frane - Kotor - vranac

23. Toma Podrug - Nikola - Dicmo ${ }^{40}$

24. Mijat Nišević - Nikola - Nin - vranac

25. Dmitar Mrgić - Stipan - Skradin - dorat ${ }^{41}$

26. Petar Petković - Antun - Skradin - vranac

27. Josip Galić - Mate - Miljevci - vranac

28. Petar Pontica - Antun - Zadar - dorat ${ }^{42}$

29. Jakov Nišević - Mate - Nin - dorat

30. Antun Biachi - Petar - Zadar ${ }^{43}$

31. Pave Nimčević - Mate - Rodaljice - dorat

32. Ivan Babić - Pavao - Vinovo (Donje) - dorat

33. Antun Pranić - Antun - Drniš - dorat

34. Ilija Andrić - Rade - Drniš - dorat

35. Jure Bitunjac - Ivan - Kričke ${ }^{44}$

36. Antun Tarle/Tarlić - Antun - Velušić

37. Pave Barišić - Pave - Kričke

38. Josip Blažević - Ivan - Gorica (?)

39. Sava Uginić - Petar - Markovac

Naknadno dopisani:

1. Kornet (Cornetta): Ivan Martin Radnić - vranac

2. Trubač (Trombetta): Leonard Literić - Blaž - Zadar - dorat

3. Sedlar (Seller): Gasparo Solini - Tomaso - Vicenza - vranac

Vojnici (Soldati):

4. Jure Zulović - Obrad - Siverić - dorat ${ }^{45}$

5. Mate Barić - Mijo - Kaštela - vranac ${ }^{46}$

6. Nikola Bianchi - Petar - Zadar - vranac

7. Antun Črnja - Ivan - Istra - dorat

39 Naknadno prekrižen.

40 Naknadno prekrižen.

41 Naknadno prekrižen.

42 Naknadno prekrižen.

43 Naknadno prekrižen.

44 Naknadno prekrižen.

45 Naknadno prekrižen.

46 Naknadno prekrižen. 
8. Ante Vukorep - Mijo - vranac - dorat ${ }^{47}$

9. Pantelija Čopić - Simo - Krka - riđan ${ }^{48}$

10. Božo Marčević - Jovan - Štikovo - dorat ${ }^{49}$

11. Mijo Buleka - Mijo - Kosovo (kraj Knina) - vranac ${ }^{50}$

12. Mario Zozić - Niko - Zadar - vranac ${ }^{51}$

13. Ivan Matas - Antun - Mirlović - vranac ${ }^{52}$

14. Juraj Leva - Ivan - Knin - riđan ${ }^{53}$

15. Antun Vukorepa/Vukosoza - dorat ${ }^{54}$

16. Nikola Jurčev - Antun - Kaštela - vranac ${ }^{55}$

17. Toma Kravar - Antun - Drniš - vranac

18. Frane Lombardić - Ivan - Imotski - vranac

19. Alberto Ugolini - Dominik - Knin

20. Zuanne da Riva - Antonio - Mletci ${ }^{56}$

21. Jakov Koić - Ivan - Mirlović - dorat

22. Jure Glujić - Ivan - Žitnić - dorat ${ }^{57}$

23. Saverio Lepur - Cezar - dorat

24. Nikola Simonić - čilašs ${ }^{58}$

25. Antun Ugrinić - vranac

26. Antun Alduk - Nikola - vranac

27. Petar Brailo - Jure - Drniš - dorat ${ }^{59}$

28. Ante Maretić - Marko - Drniš - dorat

29. Antun Brailo - Jure - Trbounje

30. Jakov Radinović - Lazo - Golubić - vranac

31. Ante Puljac - Petar - Kaštel Stari - čilaš

32. Ivan Pranić - Pavao - Drniš - dorat

33. Jakov Mangarini - Josip - Zadar - vranac

34. Ivan Milić - Ivan - Zadar - dorat

35. Mate Smiljanović - Božo - Kosovo (kraj Knina) - dorat

36. David Renić - Mihajlo - Kosovo (kraj Knina)

37. Dominik Markesinović - Ivan - Knin

\footnotetext{
47 Naknadno prekrižen.

48 Naknadno prekrižen.

49 Naknadno prekrižen.

50 Naknadno prekrižen.

51 Naknadno prekrižen.

52 Naknadno prekrižen.

53 Naknadno prekrižen.

54 Naknadno prekrižen.

55 Naknadno prekrižen.

56 Naknadno prekrižen.

57 Naknadno prekrižen.

58 Naknadno prekrižen.

59 Naknadno prekrižen.
} 
Prilog 3: Sastav posade osobne satnije pukovnika Antuna Radnića, načinjen u Mletcima 31. prosinca 1796. (Archivio di Stato di Venezia, Inquisitori sopra l'amministrazione dei pubblici ruoli, b. 826, Cavalleria Croati, Reggimento Colonnello Antonio Radnich, Compagnia propria Colonnello Antonio Radnich)

1. Pukovnik (Colonnello): Antun Radnić - čilaš

2. Poručnik (Tenente): Vicko Pasini - vranac

3. Kornet (Cornetta): Ivan Dominik Sfachiotto - vranac

4. Kadet (Cadetto): Nikola Vlaso - Stalio - dorat ${ }^{60}$

5. Kaplar (Caporal): Ludovik Gaetani - Pave - vranac

6. Kaplar (Caporal): Karlo Plasogat - Antun - vranac

7. Vodnik (Marescialco): Antun Marchesini - Santo - Verona - čilaš ${ }^{61}$

8. Sedlar (Seller): Filip Guđarović (Gugiarovich) - Ivan - čilaš

9. Kurir (Forier): Frane Jurić - Petar - Skradin - vranac

10. Trubač (Trombetta): Ivan Brunelli - Antun - čilaš

Vojnici (Soldati):

11. Vid Marčić - Mijat - dorat

12. Mate Dešković - Petar - Omiš - dorat

13. Petar Dešković - Mate - Omiš - vranac

14. Petar Mirčeta - Pave - Vrlika - vranac

15. Ivan Babić - Pave - Imotski - čilaš

16. Petar Brailo - Jure - Drniš - čilaš

17. Antun Brailo - Jure - Drniš - dorat ${ }^{62}$

18. Mate Bradić - Mate - Klis - vranac

19. Petar Puić/Puljić - Lazo - Imotski - dorat

20. Mate Raić - Frane - Zagora - dorat

21. Frane Suprag - Šimun - vranac $^{63}$

22. Ivan Ricedonić - Petar - Istra - vranac

23. Petar Manzoni - Vicko - Split - čilaš

24. Petar Grgić - Grgo - dorat

25. Frane Zubranić - Frane - Zadar - dorat ${ }^{64}$

26. Petar Milić - Brne - čilaš

27. Antun Zubar - Frane - dorat

28. Frane Santi - Josip - čilaš

29. Frane Rušić - Matija - dorat

30. Ivan Krstitelj Agostini - čilaš

31. Toma Frakanelić - Marko Antun - vranac ${ }^{65}$

60 Naknadno prekrižen.

${ }_{61}$ Naknadno prekrižen.

62 Naknadno prekrižen.

63 Naknadno prekrižen.

64 Naknadno prekrižen.

65 Naknadno prekrižen. 
32. Bernard Gattesco - Josip - dorat ${ }^{66}$

33. Karlo Dešković - Mate - Omiš - dorat

34. Luigi Baroncin - Franjo - Istra - čilaš

35. Juraj Tiozzi - Antun - Schiavonia - čilaš ${ }^{67}$

36. Nikola Grego - Andrija - Pula - dorat ${ }^{68}$

37. Petar Getti - Marko - Istra - dorat

38. Petar Graselli - Ivan - Poreč - vranac

39. Joakim Benvenuti - Petar - Kopar - vranac ${ }^{69}$

40. Matija Pahor - Antun - Piran - vranac ${ }^{70}$

41. Luigi Sprochen - Ivan - Piran - vranac ${ }^{71}$

42. Ivan Saoro - Antun - Rovinj - riđan

43. Antun Meneghello - Antun - Poreč - riđan

44. Antun Menini - Ivan - Istra - vranac

45. Lazar Borio - Jerolim - Kopar - dorat ${ }^{72}$

46. Antun Bugnera - Santo - Umag - vranac ${ }^{73}$

47. Gaetan Burdin - Antun - Stari Grad - dorat ${ }^{74}$

48. Bonaventura Lazzari - Stjepan - Schiavonia - dorat

49. Josip Antonović - Grgur - Marčana - vranac ${ }^{75}$

50. Josip Radin - Bartol - Istra - dorat

51. Ivan Schiavoncin - Dominik - Istra - dorat

52. Franjo Donato - Vicko - Zadar - vranac ${ }^{76}$

53. Franjo Minetić - Franjo - Istra - vranac

54. Bartol Maržić/Maršić - Božo - Istra - vranac ${ }^{77}$

55. Andrija Fauritto - Franjo - Istra - dorat ${ }^{78}$

56. Gaetan Pasini - Vicko - čilaš ${ }^{79}$

57. Matija Putešić - Frane - vranac ${ }^{80}$

58. Lovro Gelsomnić - Bartol - Istra - vranac

59. Ivan Kažotić - Antun - Trogir - vranac ${ }^{81}$

66 Naknadno prekrižen.

67 Naknadno prekrižen.

68 Naknadno prekrižen.

69 Naknadno prekrižen.

70 Naknadno prekrižen.

71 Naknadno prekrižen.

72 Naknadno prekrižen.

73 Naknadno prekrižen.

74 Naknadno prekrižen.

75 Naknadno prekrižen.

76 Naknadno prekrižen.

77 Naknadno prekrižen.

78 Naknadno prekrižen.

79 Naknadno prekrižen.

80 Naknadno prekrižen.

81 Naknadno prekrižen. 
60. Antun Tajapetrović - Anđelo - Istra - vranac ${ }^{82}$

61. Antun Karminatović - Ivan Krstitelj - Istra - vranac ${ }^{83}$

62. Santo Pozeborić - Ivan - Istra - dorat ${ }^{84}$

63. Marko Sfachiotto - Nikola - Zadar - dorat ${ }^{85}$

64. Dominik Pirka - Krstitelj - Pula - vranac ${ }^{86}$

65. Dominik Rogoščić - Matija - Fažana - dorat ${ }^{87}$

66. Filip Modena - Jakov - čilaš ${ }^{88}$

Naknadno dopisani:

1. Timpanist (Timpanista): Antonio Salsi - Pietro - Mletci - vranac ${ }^{89}$

2. Kapelan (Cappellano): Šimun Perić - vranac

Vojnici (Soldati):

3. Luigi Moretti - Antonio - vranac

4. Franjo Petrović - Božo - dorat

5. Ivan Krstitelj Fažolić - Bartol - čilaš

6. Ivan Amat - Vicko - Trogir - vranac

7. Ivan Dobrić - Ivan - Trogir - vranac

8. Josip Vuletić - Damjan - Trogir - vranac

9. Damjan Vuletić - Ivan - Trogir - vranac ${ }^{90}$

10. Antun Vecchi - Leonard - vranac

11. Luigi Marchetti - Bartol - Istra - vranac

12. Jerolim Skanfurlić - Josip - Istra - vranac

13. Marko Jubilatić - Josip - Istra - dorat

14. Dominik - Foskolić - Antun - Istra - dorat

15. Andrija Kanelić - Ivan - Istra - vranac

Naknadno prekrižen.

Naknadno prekrižen.

84 Naknadno prekrižen.

85 Naknadno prekrižen.

86 Naknadno prekrižen.

87 Naknadno prekrižen.

88 Naknadno prekrižen.

89 Naknadno prekrižen.

90 Naknadno prekrižen. 


\section{IZVORI I LITERATURA}

\section{IZVORI:}

Republika Hrvatska, Državni arhiv u Zadru, Generalni providuri za Dalmaciju i Albaniju (HR-DAZD-1-GPDA).

Repubblica Italia, Archivio di Stato di Venezia, Inquisitori sopral'amministrazione dei pubblici ruoli (RI-ASVe-0715, Inquisitori ... pubblici ruoli).

\section{LITERATURA:}

ANDreIs, Mladen, Trogirsko plemstvo do kraja prve austrijske uprave u Dalmaciji (1805.), Trogir, 2006.

BABIĆ, Ivo, Skradin i njegovo područje u prošlosti, Skradin, 1986.

Čoralıć, Lovorka, Mletački pukovnik Ivan Krapović iz Maina (prva polovica 18. stoljeća), Arhivski zapisi, god.18, br. 2, Cetinje, 2011., 81 - 106.

ČorALIĆ, Lovorka, Od zapovjednika hrvatske konjice do gorljivih autonomaša - šibenska obitelj Fenzi (XVII. stoljeće - početak XX. stoljeća), Povijesni prilozi, god. 30, br. 41, Zagreb, 2011., 203 - 231.

Čoralić, Lovorka, Mletački časnik Nikola Visković i sastav vojnoga ljudstva njegove prekomorske pukovnije početkom 18. stoljeća, Historijski zbornik, god. LXV, br. 2, Zagreb, 2012., 365 - 385.

Čoralıć, Lovorka, Šibenski plemić Nikola Divnić (1654. - 1734.) - pukovnik hrvatske lake konjice (Cavalleria Croati), Radovi Zavoda za povijesne znanosti HAZU u Zadru, sv. 54, Zagreb - Zadar, 2012., 125 - 145.

Čoralıć, Lovorka, Zadarski patricij Šimun Nassi - pukovnik hrvatskih konjanika u mletačkoj vojsci (početak 18. stoljeća), Povijesni zbornik godišnjak za kulturu i povijesno naslijeđe, god. 4, br. 5, Osijek, 2012., 7 - 31.

ČorALIĆ, Lovorka, Zadarski patricij Lujo Detriko (1672. - 1749.) - zapovjednik hrvatske konjice (Cavalleria Croati), Zbornik Odsjeka za povijesne znanosti Zavoda za povijesne i društvene znanosti HAZU, sv. 32, Zagreb, 2014., 99 129.

Čoralić, Lovorka, Albanski vojnici u mletačkim prekojadranskim kopnenim postrojbama (18. stoljeće), Povijesni prilozi, god. 37, br. 54, Zagreb, 2018., 183 $-214$.

ČorAlić, Lovorka, KATušić, Maja, Andrija Mladinić i Mihovil Anđelo Filiberi - časnici postrojbe Croati a cavallo (iz društvene i vojne povijesti Dalmacije u XVIII. stoljeću), Povijesni prilozi, god. 28, br. 37, Zagreb, 2009., 247 - 282. 
Čoralić, Lovorka, KATušić, Maja, Od afričke obale do dalmatinske prijestolnice - mletački general Marko Antun Bubić (1735. - 1802.), Zbornik Odsjeka za povijesne znanosti Zavoda za povijesne i društvene znanosti HAZU, sv. 28, Zagreb, 2010., $139-172$.

Čoralić, Lovorka, Katušıć, Maja, Kotorski plemići Frano Buća, Gabrijel Vraćen i Nikola Paskvali - časnici mletačkih prekojadranskih vojnih postrojbi (prva polovica XVIII. st.), Povijesni prilozi, god. 31, br. 42, Zagreb, 2012., 249 $-273$.

Čoralić, Lovorka, KATUšić, Maja, Peraštanin Tripun Štukanović (+ 1769) pukovnik mletačkih oltramarina, Anali Zavoda za povijesne znanosti HAZU u Dubrovniku, sv. 50, Zagreb - Dubrovnik, 2012., 385 - 410.

Čoralić, Lovorka, KATUŠIć, Maja, Hrvatski vojnici u posljednjim danima Mletačke Republike - kapetan Nikola Bolica i njegovi Fanti oltramarini, u: Ascendere historiam. Zbornik u ćast Milana Krubeka, ur. Marija Karbić, Hrvoje Kekez, Ana Novak i Zorislav Horvat, Zagreb, 2014., 197 - 208.

Čoralić, Lovorka, KATušić, Maja, Pukovnici, bojnici, kapetani - časnici iz kaštelanske obitelji Kumbat u službi Mletačke Republike (18. stoljeće), Radovi Zavoda za povijesne znanosti HAZU u Zadru, sv. 57, Zagreb - Zadar, 2015., $145-183$.

ČorAlić, Lovorka, KATUšić, Maja, Jerolim Smeća - pukovnik mletačkih prekomorskih pješačkih postrojbi (druga polovica 18. stoljeća), Radovi Zavoda za povijesne znanosti HAZU u Zadru, sv. 59, Zagreb - Zadar, 2017., $289-314$.

Čoralıć, Lovorka, KATUšıć, Maja, Kotoranin Tripun Gregorina (1719-1791) - pukovnik hrvatskih konjanika (Croati a cavallo), Anali Zavoda za povijesne znanosti HAZU u Dubrovniku, sv. 55/2, Zagreb - Dubrovnik, 2017., 375 406.

Čoralić, Lovorka, Markulin, Nikola, Kotorski plemić Benedikt Paskvali (1704. - 1790.) - zapovjednik mletačkih prekomorskih pješačkih postrojbi, Acta Histriae, god. 26, sv. 2, Koper, 2018., 393 - 428.

Čoralić, Lovorka, MARKulin, Nikola, Šibenski plemić Mihovil Zavorović - zapovjednik mletačkih pješačkih postrojbi u završnim desetljećima 18. stoljeća, u: Zbornik Šibenik od prvog spomena, ur. Iva Kurelac, Šibenik Zagreb, 2018., $301-317$.

Čoralić, Lovorka, MARKulin, Nikola, Vojni inženjer Antun Marković (u. 1767.) i njegova pješačka pukovnija, Radovi Zavoda za povijesne znanosti HAZU u Zadru, sv. 60, Zagreb - Zadar, 2018., 167 - 204. 
Čoralić, Lovorka, Markulin, Nikola, Kotorski plemić i zapovjednik mletačkih prekomorskih pješaka Stjepan Buća i sastav njegove pukovnije (prva polovica 18. stoljeća), Povijesni prilozi, god. 38, br. 56, Zagreb, 2019., $261-294$.

Čoralić, Lovorka, MARKulin, Nikola, Trogirski plemići Michieli Vitturi visoki časnici mletačkih prekomorskih kopnenih postrojbi u drugoj polovici 18. stoljeća, Radovi Zavoda za povijesne znanosti HAZU u Zadru, sv. 61, Zagreb - Zadar 2019., 361 - 405.

Čoralić, Lovorka, Prijatelj PAvičić, Ivana, Prilog poznavanju djelovanja graditeljske obitelji Scotti (crkva sv. Grgura u Lepenicama u trogirskoj zagori), Croatica christiana periodica, god. XXVI, br. 49, Zagreb, 2002., 137 - 145.

GrgIĆ, Ivan, Obnova vlasteoske općine u Skradinu 1706. godine, Zadarska revija, br. 2, Zadar, 1958., 152 - 153.

Heyer von Rosenfeld, Carl Georg Friedrich, Der Adel des Königreichs Dalmatien, Nürnberg, 1873.

Kosor, Karlo, Drniš pod Venecijom (Prilog poznavanju prošlosti Drniša), Kačić. Zbornik Franjevačke provincije Presv. Otkupitelja, sv. 7, Split, 1975., 5 - 79.

Kosor, Karlo, Drniška krajina za turskoga vladanja, Kačić. Zbornik Franjevačke provincije Presv. Otkupitelja, sv. 11, Split, 1979., 125 - 194.

Markulin, Nikola, Mletačka vojna organizacija u Dalmaciji i Boki od Morejskog rata (1684. - 1699.) do Požarevačkog mira 1718. (doktorska disertacija, Sveučilište u Zadru), Zadar, 2015.

PERA, Jakov, Povijest Kaštel Štafilića, Kaštela, 1997. 
Lovorka ČORALIĆ

\section{DALMATIAN FAMILY RADNIĆ IN THE MILITARY HISTORY OF DALMATIA (17th - 18th CENTURY)}

\section{SUMMARY}

The central issue of this paper was the analysis of archival material and historiographical data relating to the Dalmatian family Radnić, its origins and role in the military history of Dalmatia, and the broader area of Venetian acquisitions from the late 17th to late 18th century. The analysis is based on research of the material kept in the Archivio di Stato di Venezia (Inquisitori sopra l'amministrazione dei pubblici ruoli fund) and the State Archives in Zadar ( the holdings of the General Providuri of Dalmatia and Albania). Based on the above material, the first beginnings are found of a concrete mention of families in Venetian sources ( late17th century). Information is also revealed about their further involvement in Venetian overseas ground troops, primarily those related to the cavalry, elite troops known as Cavalleria Croati or Croatia a cavallo. The paper follows the activities of individual family members in the Venetian army (primarily in the cavalry) in chronological order. Special attention is paid to Captain Ivan (c. 1680 - 1756), active during the Second Morean War, and his son Antun (1723 - 1799). They achieved the rank of colonel at the very end of the Venetian Republic. In this context, along with data on their promotion, a detailed analysis of the composition of the companies they personally commanded is given, and the native origin of their military personnel is pointed out.

In conclusion it is highlighted that the Radnićes, so far little known and generally not seriously treated in historiography, were among Dalmatian families that deserve closer research. This ultimately would shed additional light on some lesser-known facts from the military and social history of Dalmatia and Venetian-Dalmatian relations in the last centuries of the early modern age.

Appendices at the end of the paper also contain lists of the composition of their companies, made according to the material from the Archivio di Stato di Venezia.

Keywords: Radnić family, Dalmatia, Venetian Republic, military history, early modern age. 